$\sqrt{3}$

J. Bio-Sci. 23: 57-65, 2015

ISSN 1023-8654

http://www.banglajol.info/index.php/JBS/index

\title{
USE OF DIFFERENT NON-CHEMICAL METHODS FOR THE MANAGEMENT OF ADULT CALLOSOBRUCHUS MACULATUS (F.) (COLEOPTERA: BRUCHIDAE) IN STORED CHICKPEA
}

\author{
SHA Mahdi", M Hasan, I Mahfuz and M Khalequzzaman \\ Department of Zoology, University of Rajshahi, Bangladesh
}

\begin{abstract}
The efficiency of physical factors (dry heat, low temperature and UV-radiation), leaf powders of Neem (Azadirachta indica A. Juss.), Bichuti (Flacourtia indica Merr.) and Parthenium weed (Parthenium hysterophorus L.) and two insecticides (Salvo and Amithrin plus) was evaluated against Callosobruchus maculatus (F.). For dry heat treatment, the calculated $\mathrm{LD}_{50}$ values for $C$. maculatus were $56.92,54.26$, $52.27,50.76,49.09,50.55$ and $29.59^{\circ} \mathrm{C}$ after $50,60,70$, and 80 minutes, $24,36,48 \mathrm{~h}$ of treatment respectively, and the $L D_{50}$ values were 58.61 and $5.18^{\circ} \mathrm{C}$ at 1 and $2 \mathrm{~h}$ for low temperature treatment respectively. $\mathrm{LT}_{50}$ values of the treatment of UV-radiation were $48.63,29.89,17.54,11.11,5.93$ and $1.35^{\circ} \mathrm{C}$ for the exposure period of $24,36,48,60,72$ and $48 \mathrm{~h}$ respectively. The calculated $L_{50}$ values of leaf powder were $3.38,3.15,2.88,2.45$ and $2.40 \mathrm{mg} \mathrm{cm}^{-2}$ for $A$. indica, $3.91,3.80,3.55,3.30$, and 3.08 for $F$. indica, 12.11, 4.35, 1.86, 1.49, and 1.36 for P. hysterophorus after $12,24,36,48$ and $60 \mathrm{~h}$ of treatment respectively. The calculated LD 50 values were $0.64,0.33,0.23,0.04$ and $0.008 \mathrm{mg} \mathrm{cm}^{-2}$ for Salvo and $0.35,0.23,0.09,0.08$ and $0.01 \mathrm{mg} \mathrm{cm}^{-2}$ for Amithrin plus at 12, 24, 36, 48 and $60 \mathrm{~h}$ respectively. The order of effectiveness of physical factors was dry heat $>$ low temperature $>$ UVradiation. On the other hand, the order of toxicity of plant powders was $F$. indica $>A$. indica $>P$. hysterophorus. In case of insecticides it was Amithrin plus >Salvo. The findings suggest that physical factors and plant leaf powders can be used in integration with other bio rational approaches.
\end{abstract}

Key words: C. maculatus, dry heat, low temperature, non-chemical methods, plant powders, toxicity, UV-radiation Introduction

Callosobruchus maculatus (F.) (Coleoptera: Bruchidae) is a major pest of several stored pulses and usually found in Southeast Asia including Bangladesh, and the loss caused to stored grain was 55-69\% weight loss and 45.6-66.3\% loss in protein substance for chickpea (Alam 1971, Gugar and Yadav 1978). Pest management through temperature application (dry heat and low temperature) is receiving renewed interest as a non-chemical method with lack of residue problem (Hallman and Denlinger 1999). It is also one of the most promising bio-rational insect management tools for farm stored grain and grain processing industries (Fields 1992, Dosland et al. 2006, Phillips and Throne 2010). Low temperature control is also currently used along with other pest management techniques to kill insects within a store. Low temperatures have been used to successfully control insect populations in the fur and food industries for over a century. There are a few studies that have examined the management of bruchids by dry heat and low temperatures (Hallman and Denlinger 1999, Dosland et al. 2006).

The possible use UV-radiation as an alternative treatment method in storage premises was used in the laboratory. Experiments with UV-rays, for the management of coleopteran pests have shown to be very promising. Calderon et al. (1985) reported that the egg-hatching in Tribolium castaneum was negatively

*Author for correspondence: mahdi_ru@yahoo.com 
affected by UV-radiation, whereas Sharma and Dwevedi (1997) observed adverse influences of UV-rays on the egg-to-adult development of $C$. chinensis L. Many of the plants use as protectants have a strong smell whichrepels or kills insect. Plant powders reduce oviposition in bruchids under laboratory conditions (lqbal and Poswal 1995). The plants, A. indica kernel powder, Tridax procumbens (L.) and A. squamosa seed powder control C. chinensis and C. maculatus (Ali et al. 1981, Sowunmi and Akinnusi 1983, Bhaduri et al. 1985). A. indica seed kernel applied to pea seeds reduced damage by $C$. chinensis over a three month storage period by reducing F1 adult progey (Kumari et al. 1990). The efficacy of diatomaceous earth in mixed formulation with other dusts and an insecticide against $C$. chinensis and $C$. maculatus was reported by Mahdi and Khalequzzaman (2012).

Different non chemical control methods against pulse beetle were thus evaluated. The present research was designed to find out the potentiality of some non-chemical methods viz., dry heat, low (cold) temperature, UV-radiation, leaf powders of Azadirachta indica A. Juss., Flacourtia indica Merr. and Parthenium hysterophorus $\mathrm{L}$. and two insecticides as reference for the control of $C$. maculatus.

\section{Materials and Methods}

Test insect: C. maculatus used in the experiments was collected from a private store house of Rajshahi, Bangladesh. The cultures were maintained in the Crop Protection and Toxicology Laboratory, Department of Zoology, University of Rajshahi. For continuous and huge supply of the beetles, mass cultures were maintained in earthen pots $(3000 \mathrm{ml})$ and sub-cultures in glass jars $(500 \mathrm{ml})$ or beakers $(500 \mathrm{ml})$ with the food medium.

Food medium: The chickpea, Cicer arietinum seeds were used as food medium for $C$. maculatus throughout the experiment. The seeds were kept in an oven and/or incubator for sterilization, about $24 \mathrm{~h}$ at $60^{\circ} \mathrm{C}$ to disinfest them. Then the seeds were thoroughly washed with tap water to remove dusts and carefully sundried having 13-14\% moisture content. The sterile foods were then preserved in air tight glass jars (1000 ml) in order to impede further infestation.

Dry heat: One hundred chickpea seeds and 30 adults (1-2 days old) of $C$. maculatus were kept in a petri dishes $(90 \mathrm{~mm})$ in the dry air oven at 50,55 and $60 \pm 1^{\circ} \mathrm{C}$ for exposure periods of $50,60,70$ and 80 minutes, 24,36 and $48 \mathrm{~h}$ for dry heat treatment. The treated and control batch at $29 \pm 1^{\circ} \mathrm{C}$ were maintained in 3 replications. Adult mortality was recorded after the exposure period of each treatment.

Low temperature: One hundred chickpea seeds and 30 adults of $C$. maculatus (1-2 days old) in a petri dish $\left(90 \mathrm{~mm}\right.$ ) were exposed to low temperatures at 5,1 and $-4 \pm 1^{\circ} \mathrm{C}$ for 1 and $2 \mathrm{~h}$ of treatment while control was kept at $29 \pm 1^{\circ} \mathrm{C}$. Three replicated trials were made, and adult mortality was recorded after each exposure period.

Ultra-violet radiation: A 15W germicidal lamp (GE1578) that emitted a wavelength of $254 \mathrm{~nm}(1 \mathrm{nmb}=1 \mathrm{x}$ $10-9 \mathrm{~m}$ ) and installed at the Genetics and Molecular Biology Laboratory, Department of Zoology, Rajshahi University, was used as a source of UV radiation. Time-mortality response tests were conducted at a series of irradiation exposure periods viz., 5, 10, 15, 20 and 25 minutes. For irradiation, 1-2 day old $30 \mathrm{C}$. maculatus were kept in each $90 \mathrm{~mm}$ petri dishes, and placed on table surface $12 \mathrm{~cm}$ below the lamp at above time periods. Petri dishes were then exposed to UV-rays for estimating their respective mortalities at $24,36,48$, 60,72 and $84 \mathrm{~h}$ after post-irradiation. The same number of non-irradiated insects was maintained as controls in room temperature in three replications.

Plant leaf powders: Fresh leaves of Neem (Azadirachta indica A. Juss.), Bichuti (Flacourtia indica Merr.) and Parthenium weed (Parthenium hysterophorus L.) were collected from the surroundings of the campus of 
University of Rajshahi, Bangladesh. Afterwards they were washed in running water. The plant materials were kept in shade for air-drying and then dried at room temperature $\left(25-35^{\circ} \mathrm{C}\right)$ until they become crisp dry. Powdered samples were prepared by pulverizing the dried leaves using a blender. All the plant materials were sieved repeatedly to obtain the fine dust particles. The ground samples were passed through a 25 mesh sieve to obtain fine and uniform dust. The resulting dusts were used as direct admixture to the chickpea seeds at different doses. The dust was preserved in airtight condition in polythene bags till their use. Plant leaf powder was tested individually by mixing in w/w with $10 \mathrm{~g}$ of chickpea seed at the doses of 2.594, 2.672, 2.750, 2.830, and $2.908 \mathrm{gm} \mathrm{cm}^{-2}$ for Neem, 3.301, 3.379, 3.458, 3.537 and $3.615 \mathrm{gm} \mathrm{cm}^{-2}$ for Bichuti, and 1.415, 1.493, 1.572, 1.650 and $1.730 \mathrm{gm} \mathrm{cm}^{-2}$ for Parthenium weed. Three replications and a control (without insecticide) batches were made and 30 adult beetles were released in each petri dishes. The mortality of the beetles was recorded after 12, 24, 36, 48 and $60 \mathrm{~h}$ of treatment.

Dust formulation insecticides: The commercial dust formulation "Salvo $20 \mathrm{sp"} \mathrm{and} \mathrm{"Amithrin} \mathrm{plus} 3 \%$ WDG" of Bayer Crop Science, Germany was used. Insecticide was tested individually by mixing in w/w with $10 \mathrm{~g}$ of chickpea seed at the doses of $0.031,0.049,0.063,0.079$ and $0.094 \mathrm{gm} \mathrm{cm}^{-2}, 0.094,0.129,0.157$, 0.289 and $0.220 \mathrm{gm} \mathrm{cm}^{-2}$ for Salvo and Amithrin plus respectively. Three replications and a control (without insecticide) batches were made and 30 adult beetles were released in each petri dishes. The mortality of the beetles was recorded after 12, 24, 36, 48, and $60 \mathrm{~h}$ of treatment.

Analysis of the data: The mortality percentage was corrected using Abbott's formula (Abbott 1925, Busvine 1971): where, $\mathrm{Pt}=[(\mathrm{Po}-\mathrm{Pc}) /(100-\mathrm{Pc})] \times 100$, where $\mathrm{Pt}$ is the corrected mortality $(\%), \mathrm{Po}$ is the observed mortality (\%) and Pc is the control mortality (\%). The observed data were then subjected to probit analysis according to Finney (1947) and Busvine (1971) LT 50 for lethal temperature and lethal period, and LD 50 for lethal dose were considered through the experiment. Heterogeneity is tested by chi-squared test.

\section{Results}

\section{Effect of dry heat, low temperature and UV-radiation}

The maximum $L T_{50}$ was $56.95^{\circ} \mathrm{C}$ at 50 minutes while the minimum $L T_{50}$ was $29.59^{\circ} \mathrm{C}$ at $48 \mathrm{~h}$ of treatment period for dry heat treatment to $C$. maculatus (Table 1). For low temperature treatment, the minimum $\mathrm{LT}_{50}$ was $5.18^{\circ} \mathrm{C}$ at $2 \mathrm{~h}$; however, the maximum $L T_{50}$ was not effective at $1 \mathrm{~h}$ treatment period (Table 1). For UVradiation, the maximum $L T_{50}$ was 48.63 minutes at $24 \mathrm{~h}$ while the minimum $L T_{50}$ was 1.35 minutes at $84 \mathrm{~h}$ after post-irradiation to $C$. maculatus (Table 1 ). The result shows that the $L T_{50}$ values of dry heat, low temperature and UV-radiation were decreased gradually with the increase of treatment period. Table 1 also shows the results of $95 \%$ confidence limits, regression equations $(Y)$ and $X^{2}$ of dry heat, low temperature treatment and UV-radiation on $C$. maculatus. The order of effectiveness of physical factors was dry heat $>$ low temperature $>U V$-radiation.

\section{Effect of plant leaf powders}

The maximum $L_{50}$ was $3.38,3.91$ and $12.11 \mathrm{mg} \mathrm{cm}^{-2}$ at $12 \mathrm{~h}$ while the minimum $\mathrm{LD}_{50}$ was $2.40,3.08$ and $1.36 \mathrm{mg} \mathrm{cm}^{-2}$ at $60 \mathrm{~h}$ of treatment period for leaf powders of $A$. indica, $F$. indica and $P$. hysterophorus respectively (Table 2). The result shows that these plant powders were effective against this test insect. With the increasing treatment period, the $\mathrm{LD}_{50}$ values of leaf powders were reduced remarkably. The results of $\mathrm{LD}_{50}\left(\mathrm{mg} \mathrm{cm}^{-2}\right), 95 \%$ confidence limits, regression equations $(Y)$ and $X^{2}$ of two insecticides against $C$. maculatus are presented in Table 2 . The order of toxicity of plant powders was $F$. indica $>A$. indica $>P$. hysterophorus. 
Table 1. LT ${ }_{50}, 95 \%$ confidence limits and regression equations of physical factors (dry heat, low temperature and UV-radiation) to adult C. maculates.

\begin{tabular}{|c|c|c|c|c|c|}
\hline \multirow{2}{*}{ Treatment period } & \multirow{2}{*}{$\begin{array}{l}\mathrm{LT}_{50} \\
\left({ }^{\circ} \mathrm{C}\right)\end{array}$} & \multicolumn{2}{|c|}{ 95\% confidence limits } & \multirow{2}{*}{ Regression equation } & \multirow{2}{*}{$\chi^{2}(\mathrm{df})$} \\
\hline & & Lower & Upper & & \\
\hline \multicolumn{6}{|c|}{ Dry heat } \\
\hline $50 \mathrm{~min}$ & 56.92 & 55.29 & 58.59 & $Y=-39.45881+25.33171 X$ & $0.33(1)$ \\
\hline $60 \mathrm{~min}$ & 54.26 & 52.66 & 55.90 & $Y=-32.38392+21.53968 X$ & $2.57(1)$ \\
\hline $70 \mathrm{~min}$ & 52.27 & 50.64 & 53.95 & $Y=-34.25336+22.85801 X$ & $0.93(1)$ \\
\hline $80 \mathrm{~min}$ & 50.76 & 49.21 & 52.36 & $Y=-41.04586+27.00517 X$ & $0.57(1)$ \\
\hline $24 \mathrm{~h}$ & 49.09 & 42.38 & 56.87 & $Y=-11.82663+9.939746 X$ & $2.70(1)$ \\
\hline $36 \mathrm{~h}$ & 50.55 & 35.96 & 71.05 & $Y=-2.861599+4.614365 X$ & $1.15(1)$ \\
\hline $48 \mathrm{~h}$ & 29.59 & 18.87 & 46.40 & $Y=-1.1125+4.154708 X$ & $0.42(1)$ \\
\hline \multicolumn{6}{|c|}{ Low temperature } \\
\hline $1 \mathrm{~h}$ & $58.61^{\text {ne }}$ & 5.02 & 6.84 & $Y=3.778285+0.6910058 X$ & $31.39(1)$ \\
\hline $2 \mathrm{~h}$ & 5.18 & 2.53 & 10 & $Y=4.630652+0.5164818 X$ & $67.26(1)$ \\
\hline \multicolumn{6}{|c|}{ UV-radiation } \\
\hline $24 \mathrm{~h}$ & 48.63 & 16.17 & 146.22 & $Y=3.40967+1.800528 X$ & $0.12(2)$ \\
\hline $36 \mathrm{~h}$ & 29.89 & 16.09 & 55.51 & $Y=3.842401+1.722514 X$ & $4.69(2)$ \\
\hline $48 \mathrm{~h}$ & 17.54 & 13.79 & 22.30 & $Y=1.841425+2.192907 X$ & $1.87(3)$ \\
\hline $60 \mathrm{~h}$ & 11.11 & 7.99 & 15.44 & $Y=3.121617+1.511519 X$ & $4.78(3)$ \\
\hline $72 \mathrm{~h}$ & 5.93 & 3.27 & 10.78 & $Y=3.694252+1.343494 X$ & $1.49(3)$ \\
\hline $84 \mathrm{~h}$ & 1.35 & 1.38 & 8.17 & $Y=3.775727+1.686104 X$ & $1.29(1)$ \\
\hline
\end{tabular}

ne: not effective

\section{Effect of two insecticides}

The maximum LD 50 was 0.64 and $0.35 \mathrm{mg} \mathrm{cm}^{-2}$ at $12 \mathrm{~h}$ while the minimum $\mathrm{LD}_{50}$ was 0.008 and $0.01 \mathrm{mg} \mathrm{cm}^{-2}$ at $60 \mathrm{~h}$ of treatment period for insecticide Salvo and Amithrin plus respectively (Table 3). The result shows that the $\mathrm{LD}_{50}$ values of insecticides were decreased progressively with the increase of treatment period. Table 3 also shows the results of $95 \%$ confidence limits, regression equations $(Y)$ and $x^{2}$ of two insecticides against $C$. maculatus. In case of insecticides, the order of toxicity was Amithrin plus $>$ Salvo. 
Table 2. LD $50,95 \%$ confidence limits and regression equations of three leaf powders to adult $C$. maculates.

\begin{tabular}{|c|c|c|c|c|c|c|}
\hline \multirow{2}{*}{ Leaf powders } & \multirow{2}{*}{$\begin{array}{l}\text { Treatment } \\
\text { period }(h)\end{array}$} & \multirow{2}{*}{$\begin{array}{c}\mathrm{LD}_{50} \\
\left(\mathrm{mg} \mathrm{cm}^{-2}\right) \\
\end{array}$} & \multicolumn{2}{|c|}{ 95\% confidence limits } & \multirow{2}{*}{ Regression equation } & \multirow{2}{*}{$\chi^{2}(\mathrm{df})$} \\
\hline & & & Lower & Upper & & \\
\hline \multirow{5}{*}{ A. indica } & 12 & 3.38 & 16.17 & 146.22 & $Y=3.40967+1.800528 X$ & $0.12(2)$ \\
\hline & 24 & 3.15 & 16.09 & 55.51 & $Y=3.842401+1.722514 X$ & $4.69(2)$ \\
\hline & 36 & 2.88 & 13.79 & 22.30 & $Y=1.841425+2.192907 X$ & $1.87(3)$ \\
\hline & 48 & 2.45 & 7.99 & 15.44 & $Y=3.121617+1.511519 X$ & $4.78(3)$ \\
\hline & 60 & 2.40 & 3.27 & 10.78 & $Y=3.694252+1.343494 X$ & $1.49(3)$ \\
\hline \multirow{5}{*}{ F. indica } & 12 & 3.91 & 4.38 & 146.22 & $Y=-7.750948+21.49975 X$ & $1.58(3)$ \\
\hline & 24 & 3.80 & 4.21 & 55.51 & $Y=-4.006943+15.50508 X$ & $7.21(3)$ \\
\hline & 36 & 3.55 & 3.72 & 22.30 & $Y=-2.303605+13.25912 X$ & $4.97(3)$ \\
\hline & 48 & 3.30 & 3.49 & 15.44 & $Y=-2.328491+14.10567 X$ & $0.26(3)$ \\
\hline & 60 & 3.08 & 3.56 & 10.78 & $Y=-1.06144+12.38746 X$ & $0.52(3)$ \\
\hline \multirow{5}{*}{ P. hysterophorus } & 12 & 12.11 & 2.66 & 55 & $Y=3.338045+1.534327 X$ & $2.47(3)$ \\
\hline & 24 & 4.35 & 3.26 & 57 & $Y=4.037036+1.507658 X$ & $4.51(3)$ \\
\hline & 36 & 1.86 & 0.90 & 3.86 & $Y=4.538531+1.70042 X$ & $1.77(3)$ \\
\hline & 48 & 1.49 & 1.35 & 1.65 & $Y=4.024939+5.600217 X$ & $1.05(3)$ \\
\hline & 60 & 1.36 & 1.20 & 1.55 & $Y=3.897927+8.102146 X$ & $2.63(3)$ \\
\hline
\end{tabular}

Table 3. $L D 50,95 \%$ confidence limits and regression equations of two insecticides to adult $C$. maculates.

\begin{tabular}{|c|c|c|c|c|c|c|}
\hline \multirow{2}{*}{ Insecticides } & \multirow{2}{*}{$\begin{array}{l}\text { Treatment } \\
\text { period (h) }\end{array}$} & \multirow{2}{*}{$\begin{array}{c}\mathrm{LD}_{50} \\
\left(\mathrm{mg} \mathrm{cm}^{-2}\right)\end{array}$} & \multicolumn{2}{|c|}{$95 \%$ confidence limits } & \multirow{2}{*}{ Regression equation } & \multirow{2}{*}{$\chi^{2}(\mathrm{df})$} \\
\hline & & & Lower & Upper & & \\
\hline \multirow{5}{*}{ Salvo } & 12 & 0.64 & 0.01 & 29.96 & $Y=3.372366+.8990858 X$ & 1.77 \\
\hline & 24 & 0.33 & 0.02 & 4.54 & $Y=3.635021+.894236 X$ & 0.35 \\
\hline & 36 & 0.23 & 0.01 & 4.53 & $Y=4.173747+.6000106 X$ & 3.60 \\
\hline & 48 & 0.04 & 0.02 & 0.07 & $Y=4.315999+1.023755 X$ & 1.27 \\
\hline & 60 & 0.008 & 0.0004 & 0.18 & $Y=5.04595+.7742266 X$ & 0.41 \\
\hline \multirow{5}{*}{ Amithrin plus } & 12 & 0.35 & 0.15 & 0.77 & $Y=2.024741+1.925898 X$ & 0.72 \\
\hline & 24 & 0.23 & 0.15 & 0.35 & $Y=2.24921+2.007077 X$ & 0.52 \\
\hline & 36 & 0.09 & 0.04 & 0.20 & $Y=3.927226+1.079516 X$ & 0.36 \\
\hline & 48 & 0.08 & 0.04 & 0.15 & $Y=3.483278+1.667075 X$ & 1.61 \\
\hline & 60 & 0.01 & 0.0006 & 0.55 & $Y=4.686913+1.087835 X$ & 0.01 \\
\hline
\end{tabular}




\section{Discussion}

Temperature is one of the principal factors delimitating survival and reproduction of insects. The application of hot air is an easy, simple and environment friendly method in grain processing industries. Pest management through temperature manipulation is receiving renewed interest as a non-chemical method with lack of residue problem (Hallman and Denlinger 1999). The dry heating of chickpea for 10 minutes at $120^{\circ} \mathrm{C}$ is used as one of the methods for reducing the anti-nutritional factors and reduced $46 \%$ of a-galactosides and $27 \%$ of tripsin inhibitor activity (Frias et al. 2000). Adult mortality of $C$. maculatus increased with increased duration of solarisation (exposure period to sun) in Nigeria (Lale 1998). The maximum $L T_{50}$ rate was $56.92^{\circ} \mathrm{C}$ at 50 minutes and minimum was $29.59^{\circ} \mathrm{C}$ at $48 \mathrm{~h}$ in this experiment agrees with the report of the previous works.

Mullen and Arbogast (1979) investigated the time-mortality relationships for eggs of five species of storeproduct insects, and found that the $C$. maculatus eggs to be among the most cold tolerant, with $\mathrm{LD}_{50}$ values of $2.7,1.3$ and $0.3 \mathrm{~h}$ at $-10,-15$ and $-20^{\circ} \mathrm{C}$, respectively. The efficacy of microwave radiation and cold storage on T. castaneum Herbst and Sitophilus oryzae L. was also examined by Gasemzadeh et al. (2010). There was complete egg mortality after 14 days of cold storage $\left(-18^{\circ} \mathrm{C}\right)$ and highest survival of eggs located at the centre of the bin. The present finding indicates that $L T_{50}$ value of low temperature was $5.18^{\circ} \mathrm{C}$ at $2 \mathrm{~h}$. The present study also suggested the temperature-exposure time combinations required for the control of $C$. maculatus in chickpea, which are sometimes different than previous studies.

Faruki et al. (2007) noted that UV treatment on the T. castaneum, T. confusum and the almond moth Cadra cautella decreased egg-hatching and reduced adult emergence. The growth and development in the lesser mealworm Alphitobius diaperinus has been shown to be manipulated by UV treatments on eggs, larvae, pupae and adults by a number of workers (Parween et al. 2004, Faruki et al. 2005, Begum et al. 2007). These results nicely corroborate with the findings of the present study. Adult mortality and reduced longevity in the UV irradiated insects might result from structural changes in the haemolymph as well as reduction in the total haemolymph count as demonstrated in the flesh fly Parasarcophaga ruficornis by Krishna and Srivastava (1991). The most likely explanation of the UV irradiation effects on the adult insects is that UV-C at $254 \mathrm{~nm}$ causes adjacent thymine (T) molecules of the DNA strands to dimerize, and further accumulation of these defects inhibits DNA replication, thereby rendering its harmful impacts on the exposed organism (Allen 2001). The present study thus clearly demonstrated the UV irradiated adult time-mortality response.

Pandey and Singh (1995) found that seeds of black gram could be effectively protected from damage by $C$. chinensis, by mixing the seed with dried powder of $A$. indica leaves at a rate of $100-400 \mathrm{mg}-50 \mathrm{gm}$ seed. Rajapakse et al. (1998) observed that $A$. indica gave significant reduction of oviposition and adult emergence of $C$. maculatus. The leaf powder of $A$. indica, $V$. negundo and $P$. hydropiper and their combinations were tested against $C$. chinensis on Lens esculenta seeds by Rouf et al. (1996) who reported that $P$. hydropiper leaf powder at $4 \mathrm{~g}^{-50 \mathrm{~g}}$ lentil seeds was the most effective in reducing oviposiotion and adult emergence of $C$. chinensis. Lakshmi and Venugopal (2000) tested six plant products viz., V. negundo, A. squamosa (leaf and seed). Annona calamus, Curcuma longa L., $A$. indica seed kernel dusts for their effectiveness against $C$. maculatus in chickpea seeds. It has also been reported that powders of clove and black pepper were most effective within eleven spices powders on C. maculatus in black gram seeds (Mahdi and Rahman 2008).

Pulse beetles are not advisable to mix insecticides with food grains. Nevertheless, the potential hazards for mammals from synthetic insecticides and the increase of insect resistance to pesticides has led to explore for new classes of insecticides with lower mammalian toxicity and a lower persistence in the environment (Roger and Hamraoui, 1993). In this experiment, the maximum $L T_{50}$ was $3.38,3.91$ and $12.11 \mathrm{mg} \mathrm{cm}^{-2}$ and minimum $\mathrm{LT}_{50}$ was $2.40,3.08$ and $1.36 \mathrm{mg} \mathrm{cm}^{-2}$ for Neem (A. indica), Bichuti ( $F$. indica) and Parthenium 
weed (P. hysterophorus) respectively. The findings of the present study also confirmed the toxic effects of leaves powders of $A$. indica, $F$. indica and $P$. hysterophorus and two insecticides Salvo and Amithrin plus (used as reference) on adult mortality of $C$. maculatus as admixtures in pest management strategies, especially by small scale farmers who store small amounts of pulses for consumption and planting.

These results concluded that $L T_{50} / L D_{50}$ values were dose and exposure time dependent. Mortality of pulse beetle was increased with the increase in exposure period which may clear the dose-time-mortality relationship in different treatment methods. These data also indicate the potential use of different nonchemical methods for the management of $C$. maculatus in stored chickpea. These physical factors and plant products can be used in integration with other bio-rational approaches. However, further research may be required on these aspects.

\section{Acknowledgment}

Thanks are due to Professor Dr. ASM Shafiqur Rahman, Department of Zoology, University of Rajshahi for help in preparation of the manuscript and to the Chairman, Department of Zoology, University of Rajshahi, Bangladesh for providing laboratory facilities.

\section{References}

Abbott WS (1925). A method of computing the effectiveness of an insecticide, Journal of Economic Entomology 18: 265267.

Alam MZ (1971). Pests of stored grain and other stored products and their control. Agricultural Information Service 3 R. K. Mission Road, Dhaka, Bangladesh. 361 pp.

Ali SI, Rawat RR and Sing OP (1981). Effectiveness of various forms of caused apple seed powder as seed protectant against the pulse beetle Callosobruchus chinensis (Linn.), Bulletin of Grain Technology 19(1): 53-56.

Allen J (2001). Ultraviolet radiation, how it affects life on earth. Earth Observatory, NASA, USA.

Begum M, Parween S and Faruki SI (2007). Combined effect of UV-radiation and triflumuron on the progeny of Alphitobus diaperinus (Panzer) (Coleoptera: Tenebrionidae) at different storage period, University Journal of Zoology Rajshahi University 26: 45-48.

Bhaduri N, Ram S and Patil BD (1985). Evaluation of some plant extracts as protectants against the pulse beetle Callosobruchus maculatus (F.) infesting cowpea seed, Journal of Entomological Research 9: 183-187.

Busvine JR (1971). A critical review of the techniques for testing insecticides. Commonwealth Agricultural Bureau, London $345 \mathrm{pp}$.

Calderon M, Bruce WA and Leesch LG (1985). Effect of UV radiation on eggs of Tribolium castaneum, Phytoparasitica 13: $179-244$.

Dosland O, Subramanyam BH, Sheppard K and Mahroof R (2006). Temperature modification for insect control. In: Heaps J (Ed.), Insect Management for Food Storage and Processing. American Association for Cereal Chemistry, St. Paul, MN, 89-103 pp.

Faruki SI, Das DR and Khatun S (2005). Effect of UV-radiation on the larvae of the lesser mealworm, Alphitobius diaperinus (Panzer) (Coleoptera: Tenebrionidae) and their progeny, Journal of Bio-Science 5(4): 444-448.

Faruki SI, Das DR, Khan AR and Khatun M (2007). Effects of ultraviolet (254nm) irradiation on egg hatching and adult emergence in the flour beetles, Tribolium castaneum, T. confusum and the almond moth Cadra cautella, Journal of Insect Science 7: 1-6.

Fields PG (1992). The control of stored-product insects and mites with extreme temperatures, Journal of Stored Products Research 28: 89-118. 
Finney DJ (1947). Probit Analysis: a statistical treatment of sigmoid response curve. Cambridge University Press, London, $333 \mathrm{pp}$.

Frias J, Vidal-Valverde C, Sotomayor C and Diaz-Pollan C (2000). Influence of processing on available carbohydrate content and anti-nutritional factors of chickpeas, European Food Research and Technology 210: 340-345.

Gasemzadeh S, Pourmirza AS, Safarligadeh MS and Maroufpoor M (2010). Effect of microwave radiation and cold storage on Tribolium castaneum Herbst (Coleoptera: Tenebrionidae) and Sitophilus oryzae L. (Coleoptera: Curculionidae), Journal of Plant Protection Research 50(2): 140-145.

Gugar GT and Yadav TD (1978). Feeding of Callosobruchus maculatus and Callosobruchus chinensis Linn. in green gram, Indian Journal of Entomology 40: 108-112.

Hallman GJ and Denlinger DL (1999). Temperature sensitivity and integrated pest management. In: Hallman GJ and Denlinger DL (Eds.), Temperature sensitivity in insects and application in integrated pest management. West View Press, Boulder, Colorado, 1-5 pp.

Iqbal J and Poswal MAT (1995). Evaluation of certain spices for the control of Callosobruchus maculatus (Fabricius) (Coleoptera: Bruchidae) in cowpea seeds, African Entomology 3: 87-89.

Krishna K and Srivastava US (1991). Effects of ultraviolet rays on the haemocytes of flesh fly, Parasarcophaga ruficornis F., Journal of Entomological Research 15(1): 378-381.

Kumari K, Sinha MM, Mehto DN and Hammed SF (1990). Effect of some vegetable oils as protectants against pulse beetles Callosobruchus chinensis, Bulletin of Grain Technology 28(1): 58-60.

Lakshmi LG and Venugopal MS (2000). Effectiveness of powdered plant products as seed protectants against the pulse beetle, Callosobruchus maculatus (F.) (Coleoptera: Bruchidae) in storage. In: Proceeding Entomocongress, Trivandrum, Kerala, India, 54-55 pp.

Lale NES (1998). Preliminary studies on the effect of solar heat on oviposition, development and adult mortality of the cowpea bruchids Callosobruchus maculatus (F.) in the Nigerian savanna, Journal of Arid Environments 40: 157162.

Mahdi SHA and Khalequzzaman M (2012). The efficacy of diatomaceous earth in mixed formulation with other dusts and an insecticide against the pulse beetles, Callosobruchus chinensis L. and Callosobruchus maculatus (F.), University Journal of Zoology Rajshahi University 31: 73-78.

Mahdi SHA and Rahman MK (2008). Insecticidal effect of some spices on Callosobruchus maculatus (Fabricius) in black gram seeds, University Journal of Zoology Rajshahi University 27: 47-50.

Mullen MA and Arbogast RT (1979). Time temperature-mortality relationships for various stored product insect eggs and chilling time for selected commodities, Journal of Economic Entomology 72: 476-478.

Pandey NK and Singh SC (1995). Effect of neem leaf powder on survival and mortality of pulse beetle, Callosobruchus chinensis (L.) infestation gram, Uttar Pradesh Journal of Zoology 3: 162-164.

Parween S, Faruki SI and Akhter R (2004). Growth and development of Alphitobius diaperinus (Panzer) (Coleoptera: Tenebrionidae) developing from pupae irradiated with ultra-violet ray, University Journal of Zoology Rajshahi University $23:$ 23-26.

Phillips TW and Throne JE (2010). Biorational approaches to manage stored product insects, Annual Review of Entomology 55: 375-397.

Rajapakse R, Senanayakae SGJN and Ratnasekera D (1998). Effect of five botanicals on oviposition, adult emergence and mortality of Callosobruchus maculatus Fabr. (Coleoptera: Bruchidae) infesting cowpea, Journal of Entomological Research 22(2): 1-6. 
Roger RC and Hamraoui A (1993). Efficiency of plants from the south of France used as traditional protectants of Phaseolus vulgaris L. against its bruchid Acanthoscelides obtectus (Say), Journal of Stored Products Research 29: 259-264.

Rouf FM, Sardar MA and Ahmed KS (1996). Individual and combined effect of some plant materials for protection of lentil seeds against pulse beetle, Callosobruchus chinensis L., Bangladesh Journal of Entomology 6: 13-21.

Sharma MK and Dwevedi SC (1997). Investigation on the effects of ultraviolet and infra-red light on the life cycle of Callosobruchus chinensis Linn., Journal of Advanced Zoology 18: 27-31.

Sowunmi OE and Akinnusi OA (1983). Studies on the use of the neem kernel in the control of stored cowpea beetle Callosobruchus maculatus, Tropical Grain Legume Bulletin 27: 28-31 
